\title{
Lumen
}

Selected Proceedings from the Canadian Society for Eighteenth-Century Studies

\section{The Freemasons, the Temple, and the Lost Ark}

\section{Jay Macpherson}

Volume 33, 2014

URI : https://id.erudit.org/iderudit/1026571ar

DOI : https://doi.org/10.7202/1026571ar

Aller au sommaire du numéro

Éditeur(s)

Canadian Society for Eighteenth-Century Studies / Société canadienne d'étude du dix-huitième siècle

ISSN

1209-3696 (imprimé)

1927-8284 (numérique)

Découvrir la revue

Citer cet article

Macpherson, J. (2014). The Freemasons, the Temple, and the Lost Ark. Lumen,

33, 153-172. https://doi.org/10.7202/1026571ar d'utilisation que vous pouvez consulter en ligne.

https://apropos.erudit.org/fr/usagers/politique-dutilisation/ 


\title{
The Freemasons, the Temple, and the Lost Ark
}

\author{
JAY MACPHERSON \\ Professor Emeritus, University of Toronto
}

This paper sets out to explore the interest of Freemasons, mainly English, in King Solomon's Temple during the first half of the eighteenth century, through engravings of the period. The 1740s engravings shown are from France, where English Freemasonry had arrived about 1725; they cover a period when English Masons, alarmed by the appearance in 1730 of a significant exposure, published very little.

Through much of the century before 1717 the Freemasons were growing away from the old craftsmen's guild of stonemasons, becoming to outward appearance just an early gentlemen's club. They existed independently in various centres in England, Scotland, and less certainly Ireland. What gave them a common banner (until 1717 when four old London lodges joined to form a Grand Lodge), was not a central organization but a shared tradition. They carried over from their craft some symbols, some legends, and some rituals, these last concerned almost exclusively with initiating members and then advancing them to further grades. They brought also some vocabulary, notably the word "lodge," which means both the group and its meeting-place. The guild had only two grades, Entered Apprentice and "Master or Fellowcraft": "Master" was reserved for a Fellowcraft, a fully trained stoneworker who had set up as an employer of his fellows, and also for the elected head of the local assembly or lodge, but by 1730 "Master" had been added as a third grade. While all the ceremonies question the candidate on the lore of Masonry and culminate in his taking an oath of secrecy and receiving a password, the third degree 
offers more to the imagination. It imparts a colourful legend of the murder of the master-builder of Solomon's Temple and the discovery of his body. Some creative spirit must have put this together from available traditions, now hard to trace, ${ }^{1}$ and shared it with his lodge. If other lodges then took it up and the Grand Lodge quite soon accepted it, this suggests a need to distinguish between the two groups embraced by the old second degree. ${ }^{2}$ When a fourth degree, the Royal Arch, then rather shortly emerged, this again perhaps met a need to distinguish between those who had advanced to the Master's degree and those who in addition had "passed the chair," or served as masters of their lodges.

The Royal Arch degree, created about 1740 probably in London, ${ }^{3}$ dramatizes English Masonry's other major legend: that during the rebuilding of the Temple under Zerubbabel, returned from Babylonian exile, one of the workers found an underground vault, which he entered by lifting the keystone. Here he discovered a gold plate bearing the mystic name of God. This discovery is seen as making good the loss of the Mason Word that disappeared with the murdered Master.

The Royal Arch and a lesser pair of degrees called Mark Masonry are the only additions to the original three so-called Craft degrees recognized by the English Grand Lodge. While some fourteen socalled "higher degrees" have long operated in Britain, with intriguing names like Royal Ark Mariner, Secret Monitor, and Knight Templar Priest, the Grand Lodge keeps aloof from all of these.

These further degrees, unlike the Royal Arch and Mark Masonry, are not British in origin. They were fashioned in the eighteenth century in France on the basis of Craft Masonry. The French were eager to escape from the working-class origins of that body, and perhaps more particularly inspired by the 1737 oration of Andrew Ramsay that links the early history of Freemasonry with Crusader knights. ${ }^{4}$ The new degrees seem to have been largely the work of opportunists, looking for wealth and an established place in society, playing on

1. But see Carr, "The Evolution and Ritual of the Third Degree," 315-17.

2. Carr, "More Light on the Royal Arch," 164.

3. For an argument for a French origin see Le Forestier $51 \mathrm{n} .1$.

4. Ramsay's oration as translated in Gould's History of Freemasonry 5:84-89 is available online at www.freemasons-freemasonry.com/ramsay_biography_oration. html [accessed May 31, 2010]. 
their compatriots' love of ornaments and robes and modest titles like "Emperor of the East and West."

Under the invented name of "Scottish" degrees, all accompanied with impressive trappings, the French produced a range of legends centering at first on the building of the Second Temple under Zerubbabel, and then shortly on the supposed discoveries of Templars during the Crusades. They received their name from having had quarters close to the Temple site, and were believed to have searched its foundations. Partly from France itself, and partly through the influence of the great rivals of the English Grand Lodge called the Antients, who were enthusiasts for new degrees and became the first promoters of the Royal Arch, these were soon carried to North America. There under the name of the Scottish Rite they were reorganized in the nineteenth century to become the best-known form of Masonry in the USA. The English Royal Arch degree has been absorbed into the Scottish Rite, where as one among many-number 13, Royal Arch of Solomon or Knights of the Ninth Arch-it has lost its special standing.

While other British crafts had linked their rituals and related lore to legends of patron saints, early Masons liked to refer to the building of the Tower of Babel, the first land structure mentioned in Genesis. However, it must have sunk in that the Lord did not look with favour on Babel, so their interest began to shift to the building of Solomon's Temple, the Bible's most significant structure. Since 1717, when Freemasonry took its modern form, this has remained its central legend.

Masons embraced as symbolic features of their lodges the two bronze pillars in the Temple porch, called Jachin and Boaz (1 Kings 7:21), and a non-biblical image of a floor laid out in a chequered pattern, called the "mosaic pavement." At their regular meetings, at first held in taverns, they would chalk out a lodge plan on the floor, marking the places of the officers' seats and of a few symbolic objects. Since the entrance was always between the two pillars, the floor plan in some sense represented Solomon's Temple, and is so named in some French exposés of the 1740s-lodge buildings are known as "Temples" to the

5. Le Forestier, introd., 34, 47, 53, 55 . 
present. A plan from a French pamphlet is evidently close to the floor drawings used in French as well as English lodges. ${ }^{6}$ As is usual it shows at its edges the cardinal points, with the entrance placed west as in churches and synagogues rather than east as in Solomon's Temple.? It shows prominently the pillars and the chequered floor, with a variety of lesser symbols. The steps shown at the bottom, with even a balustrade, I would guess were an addition to the original simple scheme, since they are not mentioned in the ritual. In most later drawings of this type they come as if it were packaged with the pillars and the chequered floor. Their presence suggests that the artist looked at one or more of the many engraved reconstructions of Solomon's Temple produced since the first printed Bibles. As for the chequered floor, Villalpando's 1604 engraving of the Holy of Holies shows a chequered floor, while Samuel Lee, 1659, shows a Temple ground-plan chequered throughout. ${ }^{8}$ However, this feature may come down from floors marked out in squares for setting out building plans, such as those that survive in upper rooms at York Minster and Wells Cathedral.

Though not usually incorporated in the lodge layout, the so-called "middle chamber," reached by a winding stair, is also of interest (1 Kings 6:8): here Solomon's master-masons were said to have been paid. More fully realized portrayals of the Temple began in 1731 with Benjamin Cole's frontispiece to his 2nd edition of the Freemasons' Constitutions (Fig. 1). ${ }^{9}$ He mainly wants to show the lodge's three officers with their characteristic emblems, including a different type of classical pillar associated with each, plus sun, moon and stars up top. As a backdrop appears the Temple, evidently his own version, with men working on a scaffold above the arch with winding stair shown slightly to the right. ${ }^{10}$ Another three-dimensional image appears in 1747 in France, the frontispiece to a famous exposure, Les Francs-Maçons

6. Le Secret des Francs-Maçons, 1744.

7. Mazar 100; Horne 252-57.

8. Prado and Villalpando, In Ezechielem Explanationes (Rome 1604), v. 2, reproduced in Naredi-Rainer, fig. 93; Lee, 16.

9. The Antient Constitutions of the Free and Accepted Masons. 2nd ed. London, 1731.

10. The "G," here shown on the keystone, in early use stands unequivocally for "Geometry," which from the oldest Masonic documents (Regius and Cooke, c. 1390 and c. 1410) to redactions of the early eighteenth century (Briscoe and Cole, 1724 and 1729 ) is explained as the science of which Masonry is the practice. 
écrasés (Fig. 2). ${ }^{11}$ Again the Temple is still being built or rebuilt, but here the scaffolding is collapsing and the workmen are falling off it, while a lodge-master, marked by the square and compasses hung round his neck, is tearing off his wig in despair. The catastrophe to building and builders, while a humorous foreshowing of the effect of the exposure, may also refer to the Freemasons' view of themselves as, symbolically, those charged with the rebuilding of the Temple. Its depiction can be matched up with a copperplate of the façade from 1604 by the Spanish Jesuit Juan Bautista Villalpando, completing the work of his deceased colleague Jerónimo de Prado based on Ezekiel's visions in exile of Solomon's Temple restored (Fig. 3). ${ }^{12}$ We may note, in view of some current theosophical speculations, that while Villalpando supplied cosmological, anthropometric and harmonic diagrams in association with his Temple plans, no influence from these appears in Masonic imagery. ${ }^{13}$

Two slightly earlier French exposures each have one lodge floorplan based on the regular floor-drawings and with the Temple layout to some extent superimposed (Figs. 5, 6). Les Francs-Maçons écrasés has three floor-plans mingling elements of temple and lodge. Several of these French plans (as with Fig. 7), are based on the bird's-eye-view woodcuts, from Estienne's Bible of 1546, that represent the researches of the notable Hebraist François Vatable. ${ }^{14}$. These lead the eye through three raised forecourts to the Temple building, itself consisting of the porch, the house proper, and the sanctuary (AV "oracle," 1 Kings 6: 16-23). The two pillars stand before the porch.

The legends, British and French, that develop alongside these layouts tell how either the rebuilders of the Temple who returned from exile or a group of Crusaders, usually Templars, explore the Temple's foundations and find, most often, a gold plate displaying the mystic name

11. Carr, Exposures 278.

12. Full plate reproduced in Naredi-Rainer, fig. 134. See also at http://originsofarchitecture.wordpress.com/2013/05/01/the-origins-of-architecture-according-to-thebible-a-gallery/

13. Reproduced in Naredi-Rainer, figs. 122-4.

14. See http://www.renaissance.wursten.be/Vatable_temple.htm 
of God. These stories are developed from hints in the Bible. In 2 Kings 22:8, during Josiah's repairs to the Temple his overseer finds "the book of the law," prompting a renewal of Israel's covenant with God, and in 2 Maccabees 2:4-7 the prophet Jeremiah carries the Ark with other Temple treasures to a cave to wait for the time when God will "gather his people." Later legends feature caverns or vaults under the Temple foundations. The Greek writer Philostorgius, born $364 \mathrm{CE}$, describes how when Constantine's nephew and eventual successor Julian, who had deserted Christianity, sought to please the Jews and displease the Christians by rebuilding the Temple despite Christ's prophecy that no stone of it should ultimately be left standing, workmen found a cave containing a copy of the Gospel of John. ${ }^{15}$

Some contributing legends were not Christian but Jewish. During the seventeenth century Jewish traditional learning had become much more available, and scholarly divines like John Lightfoot and Samuel Lee were reading tales of a First Stone or Foundation-Stone. ${ }^{16}$ Lee, in a chapter titled "The Mysteries laid up in the Foundation of the Temple,"17 notes as "vain and futilous" such rabbinic tales as that the world's foundation-stone and centre, placed by God, served as Jacob's pillow before Solomon re-laid it as the Temple's foundation-stone, engraved with the ineffable Name.

In other legends the divinely placed foundation-stone of the Creation comes to be that of the Temple without having to be moved. The bare outcrop of the Temple Mount (formerly Mount Moriah) that is now visible under the Dome of the Rock, the traditional (and likely) site of Solomon's sanctuary, came in time to embody the foundationstone and additionally both the rock on Mt. Moriah where Abraham prepared to sacrifice Isaac and Araunah's threshing-floor (2 Sam. 24:16-25) where David saw the destroying angel and built an altar to avert the Lord's anger. ${ }^{18}$

15. Jones 128-29.

16. See Ginzberg 1:12, 352; 7:14-16, n. 39; cf. the Lord's words to Job about the "foundations" and "cornerstone" of the earth, Job 38:4-6.

17. Lee 193: his “Epilogue," 267, mentions Jeremiah's hiding the Ark (2 Maccabees 2:4-7).

18. 2 Chron. 3:1 links Mt. Moriah (second and last occurrence of the name) with David's vision and the Temple site (cf. Lee 15). 
In 1743 John Coustos, a Swiss diamond-cutter who had belonged to both English- and French-speaking lodges in London in the 1730s, confessed to the Portuguese Inquisition that a bronze tablet with God's name, which he somehow linked with the opening words of the Gospel of John, had been found at the destruction of the Temple under "the First Stone." ${ }^{19}$ Coustos thereby furnishes evidence that even before the 1740s, when we have our first evidences of the Royal Arch, Masons were incorporating this kind of material into their official lore.

Much later, a special elaboration of Jewish tradition would be worked up for the Scottish Rite. Enoch, seventh from Adam, of whom Genesis (5:24) says that he "walked with God" and "he was not: for God took him," was a figure of great sanctity and the inventor of "all sciences and knowledge." James Anderson in The New Book of Constitutions of the Antient and Honourable Fraternity of Free and Accepted Masons (1738), transferred to him the honour, usually ascribed to Seth or the sons of Lamech, of having built the famous two pillars on which the arts and sciences were inscribed to preserve these from flood or fire (3). In a Masonic legend concocted for the Knights of the Ninth Arch and recorded in Webb's Freemason's Monitor (1818), and Bernard's Light on Masonry (1828), Enoch constructed a series of nine vaults either under the Temple or imitated by Solomon in the Temple's foundations. The ninth and deepest contained the triangular plate with the Name of God; either Enoch's pillars stand before the whole structure, or one is found shattered inside. ${ }^{21}$ Joseph Smith, clearly influenced by the Scottish Rite narrative, claimed to have seen in their cave in the Hill Cumorah for the first time in 1822, and acquired five years later the gold plates inscribed with the eventual Book of Mormon (1830). ${ }^{22}$

19. McLeod, 25.

20. Ginzberg 5:156.

21. Webb 243-56, Bernard 202-5, and particularly 524-28.

22. While Smith did not become a Mason till 1842, he could have encountered the Royal Arch legend through either available books or family members who belonged, like his uncle Hyrum. In 1832 he announced himself to be the prophet Enoch (Brooke, 153-59, 166). 
The most striking of the Masons' visual interpretations of Temple lore was made in the mid-eighteenth century. The London Company of Freemasons, the trade guild from which the modern Freemasons branched off (and which still exists), was granted in 1472 a coat-of-arms consisting of three towers and what looks like the Masons' square with the compasses laid over it (historically that is not the case: the square is just a chevron). ${ }^{23}$ The modern Freemasons' coat-of-arms ${ }^{24}$ is entirely different, and to discover why we must look at the history of the Antients.

In the 1730 s the London Grand Lodge responded to a very full and it seems accurate exposure of its rituals-Samuel Prichard's Masonry Dissected - by altering some small elements, mainly so that Freemasons could recognize those who tried to use it to gain entrance to the lodges. This evidently offended some immigrating Scots and particularly Irish brethren, who established London lodges that kept to the old forms, and who dubbed themselves the Antients while labelling the adherents of the Grand Lodge the Moderns. While the Royal Arch probably originated in London, it very early took root in Ireland, and the Antient lodges in London became its chief promoters.

The Antients soon acquired as their Grand Secretary a truly remarkable man, Laurence Dermott from Dublin, educated and articulate. With considerable Latin and at least some Hebrew, he had also a lively interest in the seventeenth-century works of Jacob Judah Leon on the Temple.

Rabbi Leon, a Portuguese Jew belonging to the community in Amsterdam, created a large model of the Temple, displayed in London in 1675 and again in 1759-60, when Dermott by his own account saw it. ${ }^{25}$ It seems probable that books by Leon and separate engravings from drawings by him regularly accompanied the model, for viewing or sale. $^{26}$

Dermott composed his Ahiman Rezon as the Antients' version of the Freemasons' constitutions. Its frontispiece showed "The Arms of the Operative or Stone Masons"-the scheme of 1472 with an added crest and pair of supporters (barely recognizable as beavers) - and

23. http://freemasonry.bcy.ca/grandlodge/seal/london.html

24. http://freemasonry.bcy.ca/grandlodge/seal/ugle.html

25. Dermott, Ahiman Rezon, London, 1764 (2nd ed.), preface xxxiv.

26. Shane 154-56. 
"The Arms of the most Ancient and Honorable Fraternity of Free and Accepted Masons." Remarks in the Preface imply that he had found this last among Leon's drawings as a proposed coat-of-arms for the masons who worked on Solomon's Temple-where of course by tradition the Masonic brotherhood was born. It is an extraordinary composition, formed of the components of Ezekiel's vision of the Cherubim-man, lion, ox, eagle-with two cherubim as supporters, the Ark of the Covenant with mercy-seat and cherubim as crest, and as motto in English and incorrect Hebrew, the phrase "Holiness to the Lord," described in Exodus (28:36, 39:40) as engraved on a gold plate attached to Aaron's mitre, and associated in Zechariah (14:20-21) with the restoration of the Temple.

The rivalry of Antients and Moderns continued until 1813, when each of them had at its head a son of George III-the Dukes of Sussex and of Kent were Grand Masters respectively of the Moderns and the Antients. As a result of their work towards reconciliation, an Act of Union was proclaimed in the same year, announcing the new United Grand Lodge of England. The resulting compromise explains both why the much more colourful Dermott/Leon coat-of-arms dominates the modern version, and why the Royal Arch, practised by the Antients as a fourth degree, is now officially seen within the English jurisdiction as a completion of the third, since the three so-called Craft degreesApprentice, Fellow-craft, and Master-had become the canonical core well before Grand Lodge became willing to recognize the Royal Arch.

Dermott left another puzzling image, this time with no explanatory comment. It is a drawing of about 1783 , showing the Ark with its cherubim standing on an altar in a vaulted chamber with a recognizable Royal Arch identified by its tipped keystone, and with a little plan of the whole chamber attached. It presumably illustrates the Jewish legend, recorded by an Amsterdam associate of Leon's, Menasseh ben Israel, of how Solomon prepared under the Ark a deep cavern sealed by a stone; Josiah, foreseeing Nebuchadnezzar's destruction of the Temple, carried out Solomon's intention by moving the Ark down there, where it still remains. ${ }^{27}$ Although there is no legend, Jewish, Masonic, or other, reporting the discovery of the Ark-or indeed

27. Israel, Conciliator 2:75-76. John Lightfoot, d. 16--, also knows this story (Temple 1087). 
recording its loss, though it seems not to have survived the Temple's destruction - the vault motif sometimes appears on Masonic badges of office. Most notably it is reworked on a panel of the extraordinary "Kirkwall Scroll"28, the treasure of an Orkney lodge. This consists of a series of panels, biblical-Masonic in content, painted in very naive style on an 18 -ft. pieced strip of sailcloth, of much-disputed date. ${ }^{29}$ In the Ark panel, note that the sun inside the arch resembles Dermott's fivepointed star; that the motif on the altar is Dermott's (or Leon's?) arrangement of lion, ox, man and eagle into a heraldic device; and that the three squared stones crossing the floor in Dermott's drawingwhich have no biblical antecedent-are also present. In fact, to put it very briefly, the scroll's donor, William Greame, had just spent some years in London, where he attended an Ancients' lodge and may well have known Dermott and seen the drawing. ${ }^{30}$

We can briefly note a connection between the Masonic legends concerning the Temple and the literature of the time. Little in mideighteenth-century Freemasonry suggests the Age of Sensibility, apart from some utterances on brotherhood and charity. But the several legends describing discoveries made in the ruins under Zerubbabel or by the Templars move beyond the available flat plans and bird's-eye layouts to open a new dimension of secret spaces found under the Temple, containing treasures from the deep past. This occurs not long before a similar move in the English novel: namely the rise of the Gothic, with its cellars that yield up either written papers or blinking captives, offering narratives that reveal an unsuspected past.

In Horace Walpole's Castle of Otranto (1764), an underground passageway linking the castle with a church and adjoining monastery and convent becomes the scene of the heroine's terrified flight; Matthew Gregory Lewis in The Monk (1795), brilliantly expands this into a whole hidden world of underground connections, including burial vaults and dungeon cells, where stories that appeared separate ultimately converge, and past and present are brought violently together. In such novels revelations from these depths often bring bad news such as the fact of incest, past or present-family ties in these tales being well pdf

28. See http://www.southchurch.mesh4us.org.uk/pdf/important/kirkwall-scroll.

29. For a factual recent discussion with full illustrations, see Cooper 173-212.

30. Cooper 203-4. 
imaged by a world of underground connections: thus a range of strong emotions may be called up with the opening up of the past. The makers of Masonic legends, starting just before heavy sensibility began to cling around the linked matters of cellars, the past, and the bonds of family, sought modestly to thrill, more mildly, with quasi-religious awe and with privileged participation in an all but immemorial brotherhood endowed with ancient secrets.

\section{Works Cited}

Anderson, James. The New Book of Constitutions of the Antient and Honourable Fraternity of Free and Accepted Masons. London, 1738.

The Antient Constitutions of the Free and Accepted Masons. 2nd. ed. London, 1731.

Bernard, David. Light on Masonry, 1828. Ed. Arturo de Hoyos. Washington, D.C.: Scottish Rite Research Society, 2008.

Brooke, John L. The Refiner's Fire: The Making of the Mormon Cosmology, 1644-1844. Cambridge: Cambridge University Press, 1994.

Carr, Harry, ed. The Early French Exposures. London: Quatuor Coronati Lodge, 1971.

—. "The Evolution and Ritual of the Third Degree." In Harry Carr's World of Freemasonry: Collected Papers and Talks London: Lewis Masonic, 1984. 288-320.

—. "More Light on the Royal Arch." In World of Freemasonry, $163-79$.

Cooper, Robert L. D. The Rosslyn Hoax? Viewing Rosslyn Chapel from a New Perspective. Hersham, Surrey: Lewis, 2006.

Dermott, Laurence. Ahiman Rezon: or, A Help to a Brother... 2nd ed. London, 1764 .

Ginzberg, Louis. Legends of the Jews. Philadelphia: Jewish Publication Society of America, 1937-38. 7 vols.

Gould, Robert Freke. History of Freemasonry. London: Thomas C. Jack, 1883-87. 6 vols.

Horne, Alexander. King Solomon's Temple in the Masonic Tradition. Wellingborough, Northamptonshire: Aquarian Press, 1972.

Israel, Manasseh ben. The Conciliator: A Reconcilement of the Apparent Contradictions in Holy Scripture...(1632), trans. E. H. Lindo. NY: Hermon Press, 1973. 2 vols. in 1.

Jones, Bernard E. Freemasons' Book of the Royal Arch. London: George G. Harrap, 1957. 
Knoop, Douglas, G.P. Jones and Douglas Hamer, eds. The Early Masonic Catechisms. 2nd ed. London: Quatuor Coronati Lodge, 1963.

Lee, Samuel. Orbis miraculum, or, The Temple of Solomon, pourtrayed by Scripture-light.... London, 1659.

Le Forestier, René, ed. Les plus secrets mystères des hauts grades de la maçonnerie dévoilés. Paris: Dorbon-Ainé [1915].

Lightfoot, John. [A Prospect of] The Temple Especially as it Stood in the Days of our Saviour (1650), in Works, ed. George Bright, London, 1684, 1: 1049-1207.

Mazar, Benjamin. The Mountain of the Lord: Excavating in Jerusalem. Garden City, NY: Doubleday, 1975.

McLeod, Wallace, ed. The Sufferings of John Coustos: A Facsimile Reprint of the First English Edition, Published at London in 1746. Bloomington, Ill.: Masonic Book Club, 1979.

Naredi-Rainer, Paul von. Salomos Tempel und das Abendland: monumentale Folgen historischer Irrtümer. Cologne: Dumont, 1994.

Shane, A. Lewis. "Jacob Judah Leon of Amsterdam (1602-75) and his Models of the Temple of Solomon and the Tabernacle." Ars Quatuor Coronatorum 96 (1983): 146-69.

Webb, Thomas Smith. The Freemason's Monitor, or, Illustrations of Masonry, 1797. Salem, Mass.: Cushing and Appleton, 1818.

I am indebted to Cheryl Jaffee, Curator of the Jacob M. Lowy Collection in the National Library, Ottawa, for assistance, and to my colleague and friend Wallace McLeod of Victoria College, Toronto, renowned Masonic scholar, for his generosity in lending books. 
The Freemasons, the Temple, and the Lost Ark $\$ 165$

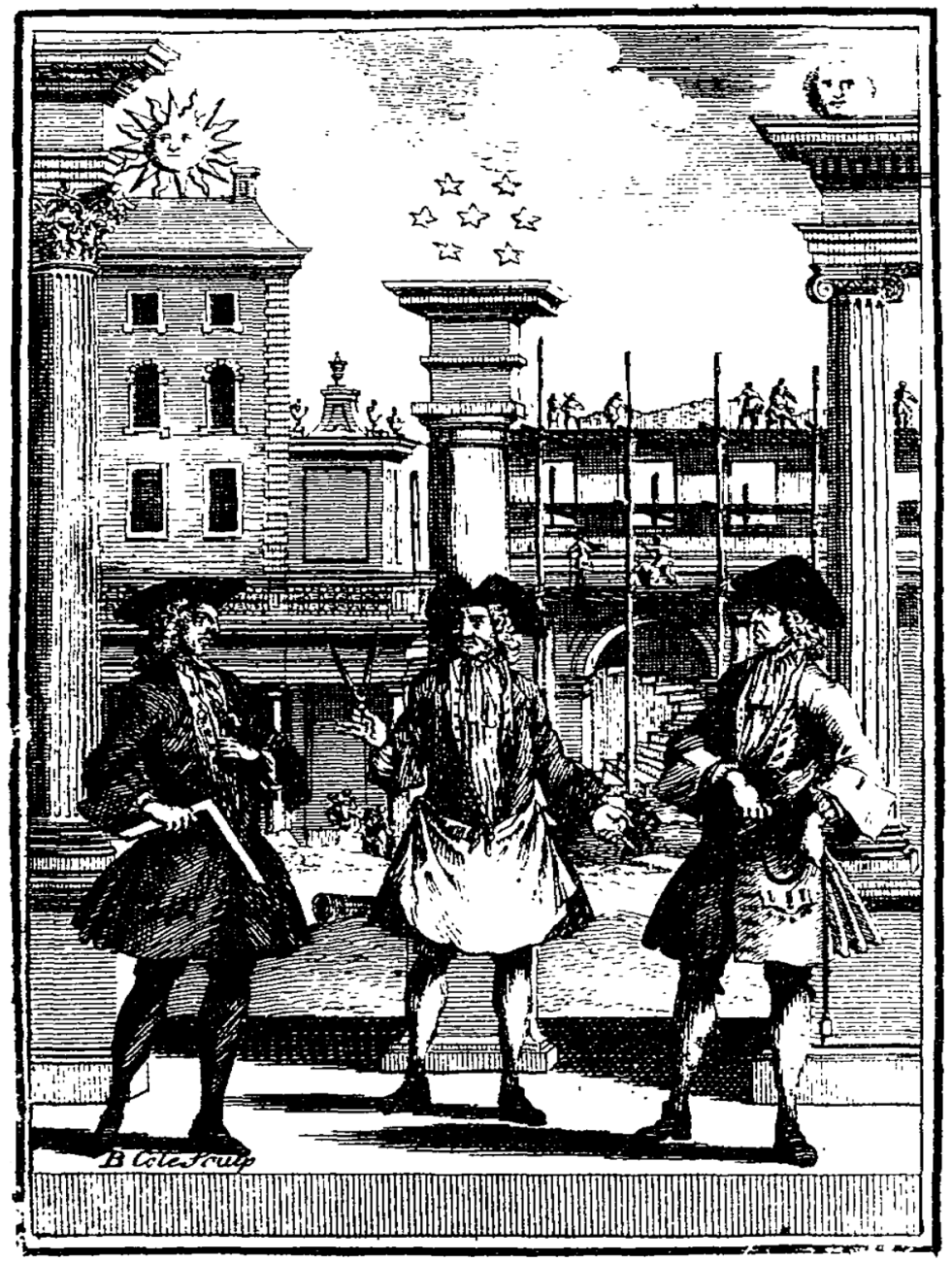

Fig. 1 The antient constitutions of the free and accepted masons, neatly engrav'd on copper plates. With a speech deliver'd at the Grand Lodge at York. Reproduced by permission. www.cengage.com/permissions From Gale. Eighteenth Century Collections Online. (C) Gale, a part of Cengage Learning, Inc. Gale Doc. No. CW3317407314. 


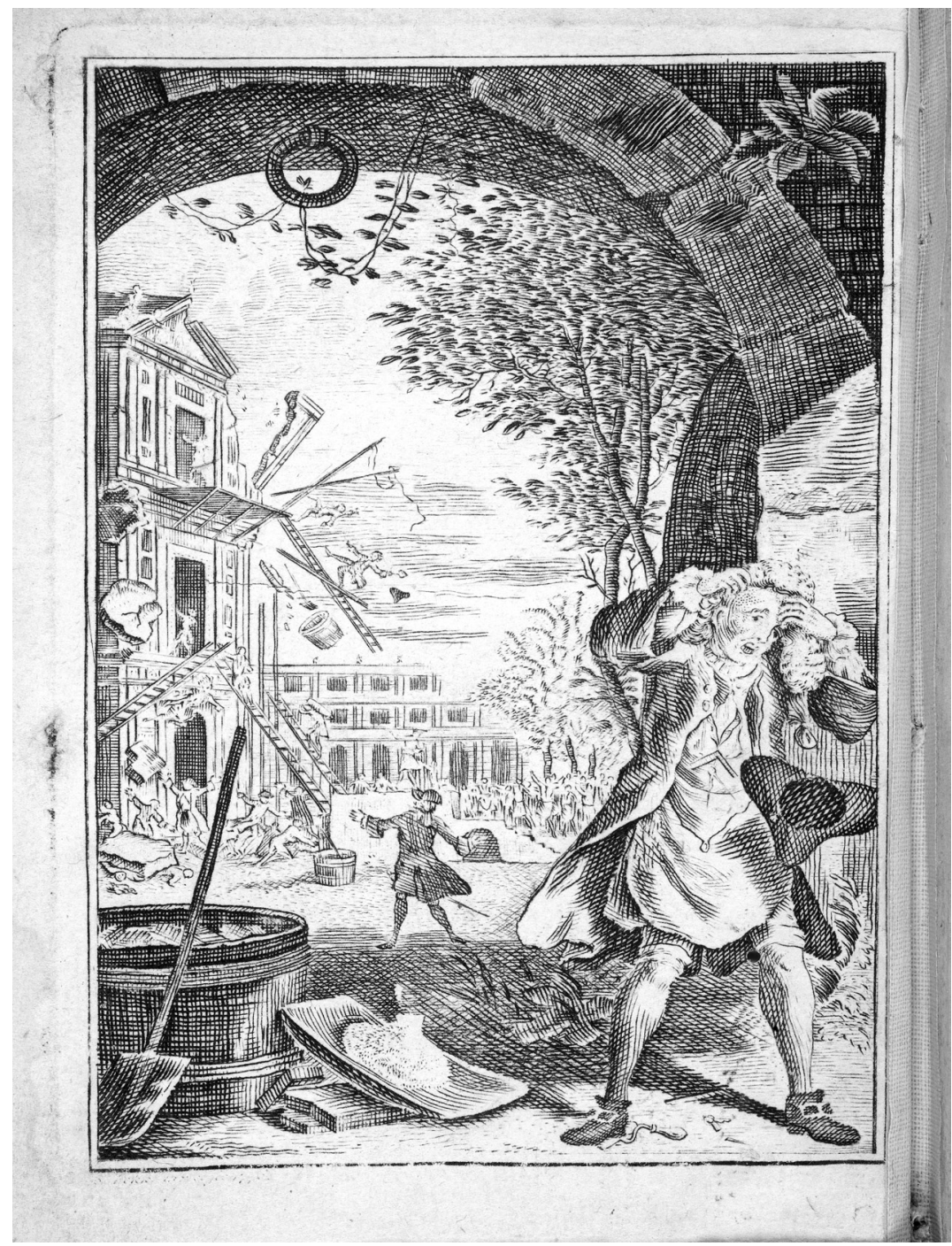

Fig. 2 Frontispiece of Les Francs-Maçons Écrasés, 1747. Digital copy with permission from Stanford University Libraries. Original materials provided by Princeton University Library, included with their permission. 


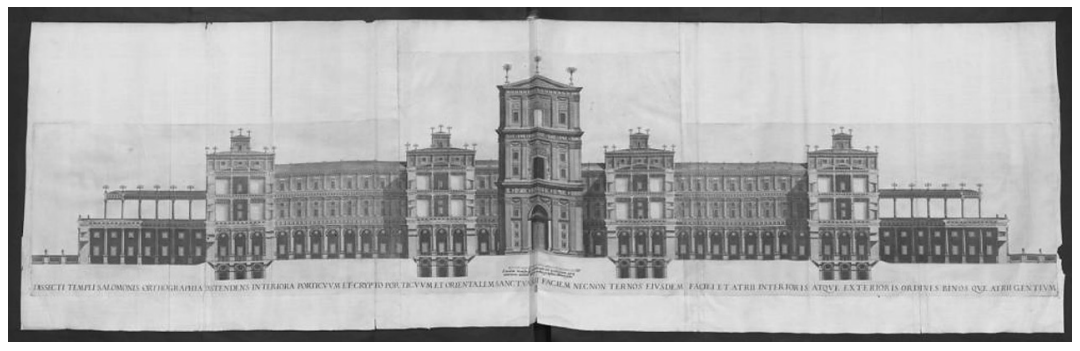

Fig. 3 East face of Temple with wing section, from J. B. Villapando, In Ezechielem Explanationes, 1604.

General Reference Collection L.17.c.4. Reprinted with permission (C) British Library Board, BLLo10013282

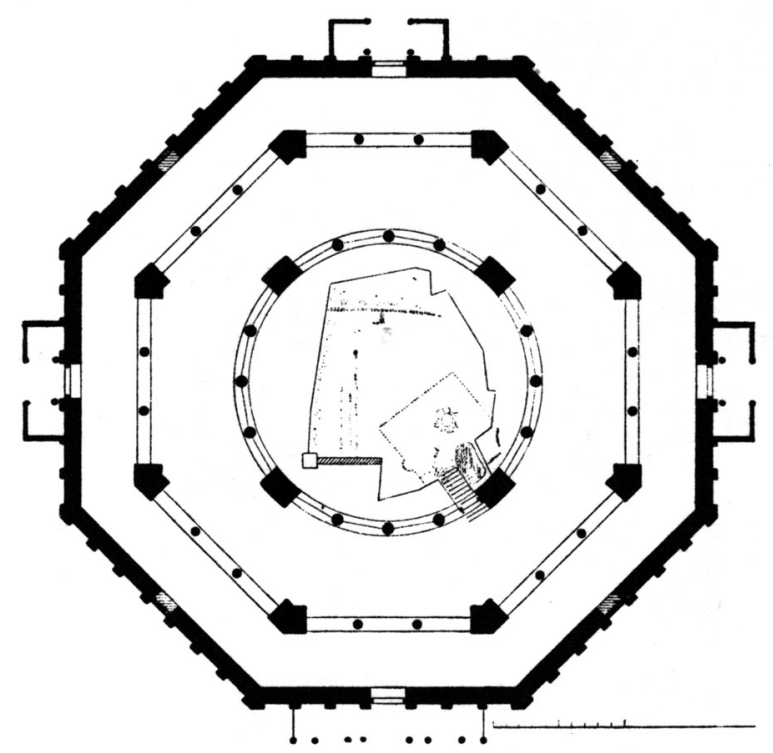

2. JERUSALEM: DER FELSENDOM.

Fig. 4 Dome of the Rock: Its centre is the rocky outcrop of the Mount surrounded by an ambulatory: steps on the south side descend to a cavern with a spring called the Well of Souls. The rock, sacred to Jews and Muslims, is the traditional site of Abraham's sacrifice, Jacob's dream, and Araunah's threshingfloor (2 Sam. 24); believed now the site of either the Temple sanctuary or the altar of sacrifice.

This image is taken from Georg Dehio/Gustav von Bezold: Abendlandes. Stuttgart: Verlag der Cotta’schen Buchhandlung 1887-1901, Plate No. 10. 


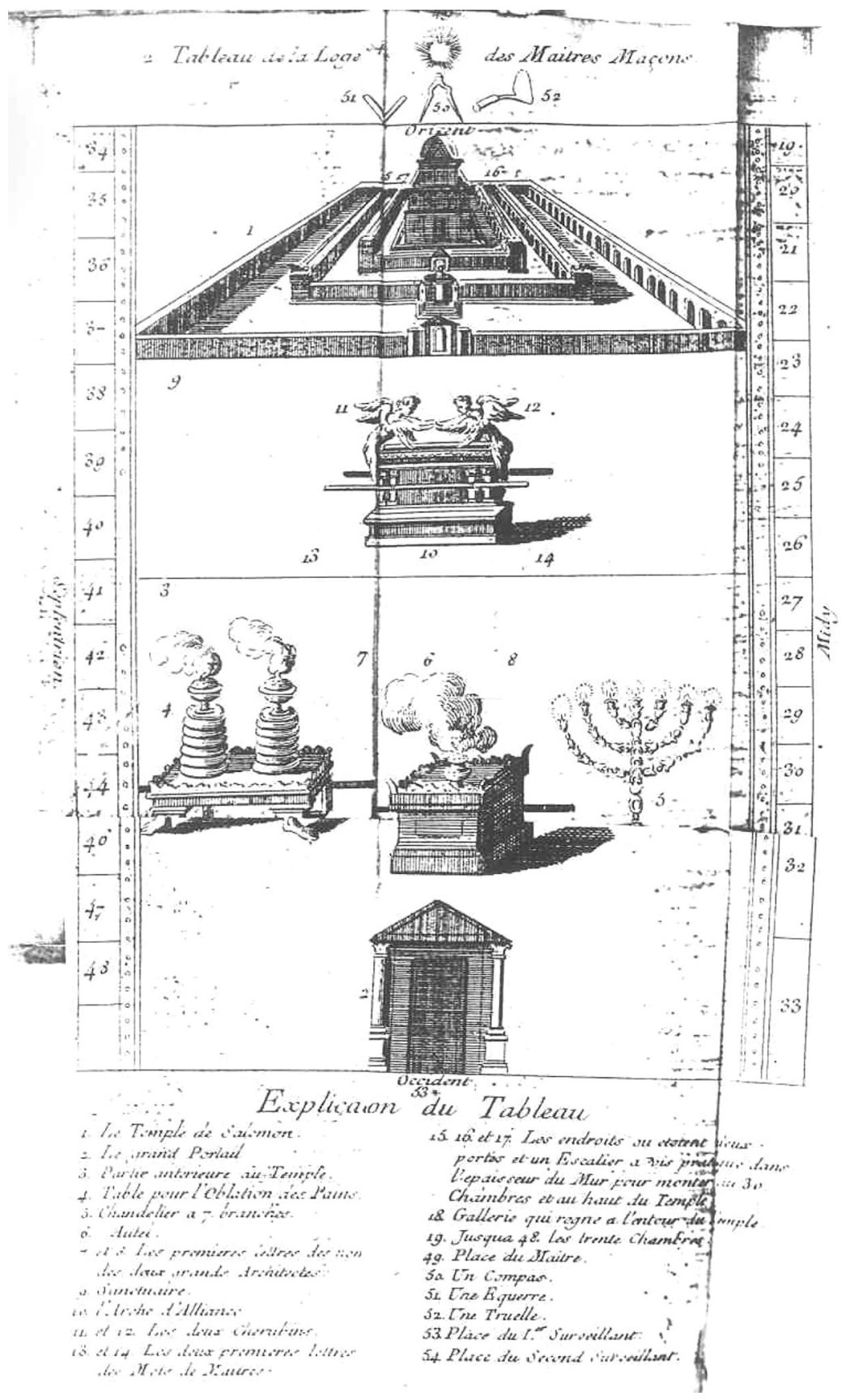

Fig. 5 Floor-drawing, Master Mason's Lodge, Le Parfait Maçon, 1744, Reprinted with permission.

(c) British Library Board, BLLo10o13282. 


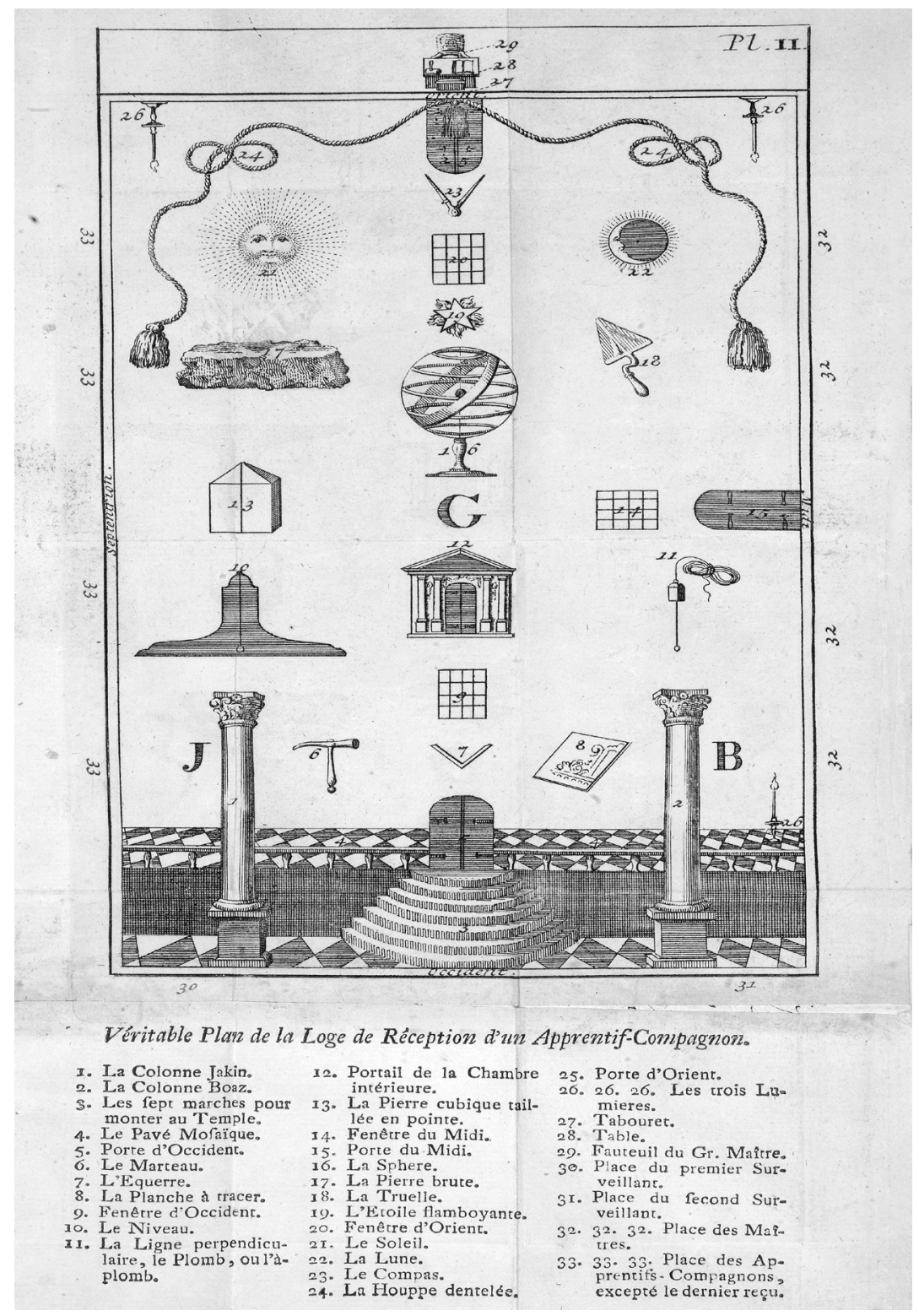

Fig. 6 Floor-drawing, "Apprentic-Fellow's Lodge," L'Ordre des FrancsMaçons Trahi, 1745, Digital copy with permission from Stanford University Libraries. Original materials provided by Princeton University Library, included with their permission. 
170 Jay Macpherson

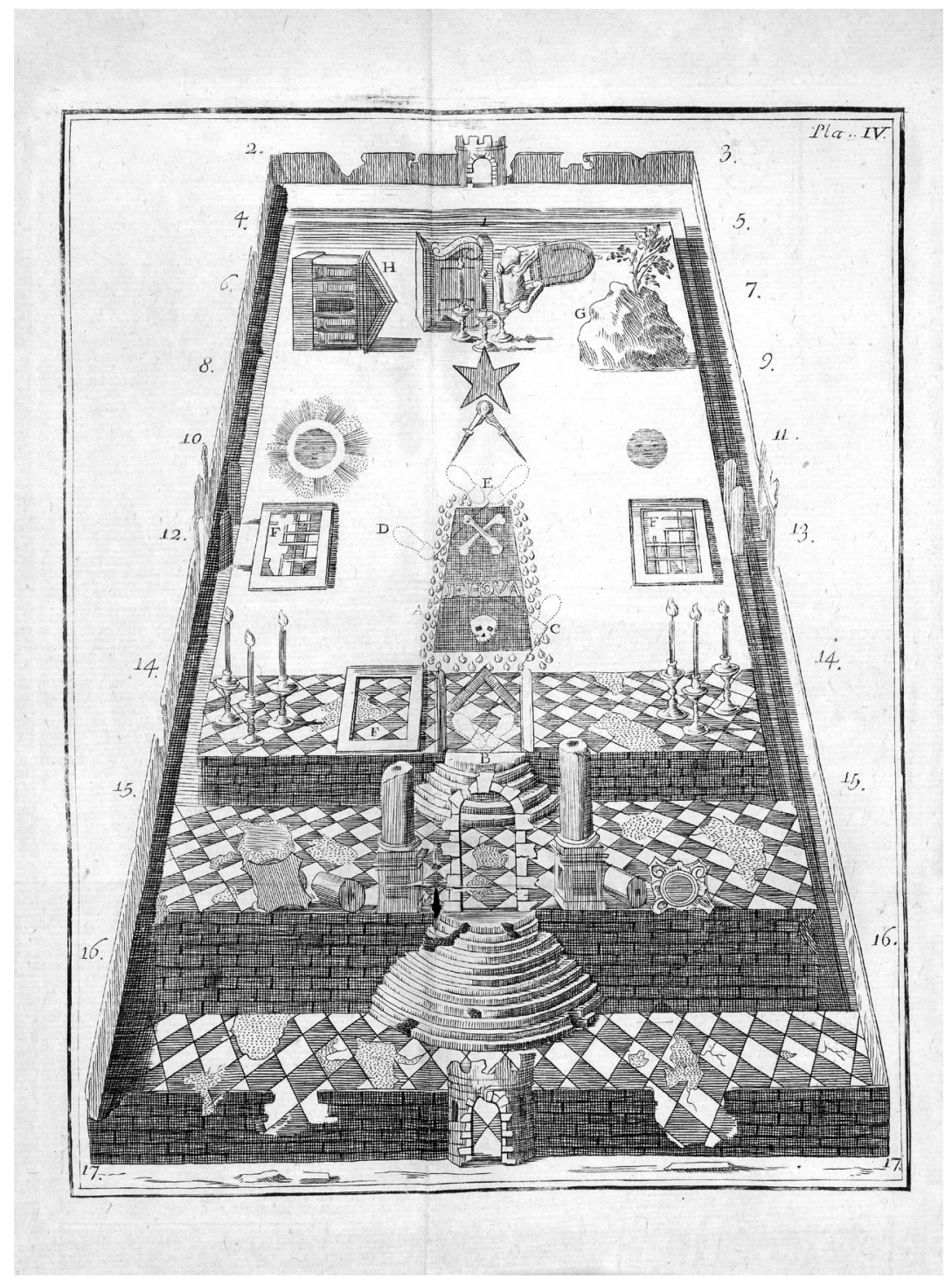

Fig. 7 Floor-drawing, "Master's Lodge as ruined Temple," Les FrancsMaçons Ecrasés, 1747. Digital copy with permission from Stanford University Libraries. Original materials provided by Princeton University Library, included with their permission. 


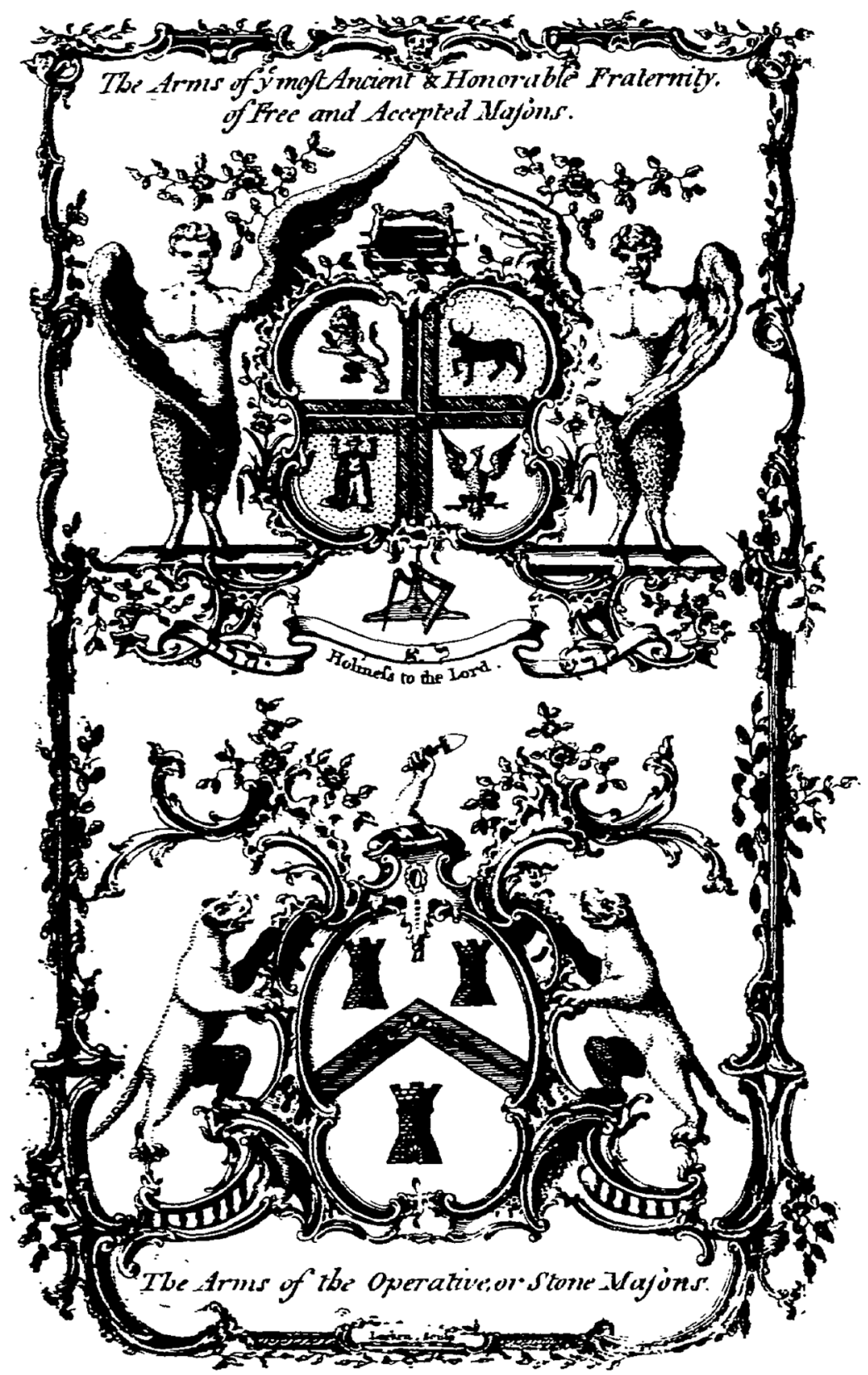

Fig. 8 Frontispiece, Ahiman rezon, or a help to all that are, (or would be) free and accepted masons, the second edition by Lau. Dermott; From Gale. Eighteenth Century Collections Online. (C) Gale, a part of Cengage Learning, Inc. Reproduced by permission. www.cengage.com/permissions 
$172 \star$ Jay Macpherson

\section{APPENDIX: Chronology}

c. 950 BCE Solomon builds ( $\left.1^{\text {st }}\right)$ Temple

c. $700 \quad$ Book of Law found during Josiah's repair of Temple (2 Kings 22)

586 Nebuchadnezzar sacks Jerusalem, destroys Temple, carries Jews into exile

c. 573 Ezekiel in exile has vision of rebuilt Temple

$520 \quad$ Return under Zerubbabel, who completes $2^{\text {nd }}$ Temple

c. $20 \quad$ Herod pulls down $2^{\text {nd }}$ Temple, builds $3^{\text {rd }}$, builds up Temple Mount

$70 \mathrm{CE} \quad$ Romans under Titus destroy $3^{\text {rd }}$ Temple

c. 336 Constantine builds circular domed church over Holy Sepulcher, west of Temple Mount

362-63 Julian attempts to rebuild Temple

691 Conquering Arabs bui8ld Dome of Rob on Temple site, modelled on Holy Sepulcher; they build also El-Aqsa as headquarters - thence called Templars

$1291 \quad$ Final defeat of Crusaders

1472 Charter of London Company of Masons

1717 Four old lodges meet to form Grand Lodge

1751 Antients form rival Grand Lodge

1813 Union of Antients and Moderns as United Grand Lodge of England 